\title{
Penerapan Media Pembelajaran Berbasis Video Animasi pada Materi Laju Reaksi dan Faktor-Faktor yang Mempengaruhi Laju Reaksi
}

\author{
Adelia Mewengkang ${ }^{*}$, Meytij J. Rampe ${ }^{a}$, Septiany Ch. Palilingan ${ }^{a}$
}

a Pendidikan Kimia, FMIPA, Universitas Negeri Manado, Minahasa, Tondano Selatan, 95618, Indonesia

INFO ARTIKEL

\begin{tabular}{l}
\hline Diterima 24 Februari 2020 \\
Disetujui 30 Juni 2020 \\
\hline Key word: \\
Animation video \\
Learning Outcomes \\
Reaction rate
\end{tabular}

Kata kunci:

Video Animasi

Hasil Belajar

Laju Reaksi

\begin{abstract}
A B S T R A C T
The purpose of this study was to determine the average learning outcomes of students with animated video media. This research is an experimental study in class XI MIA with one experimental class and one control class each class consisting of 30 students. The results of this study are the average for the experimental class of 86.40 and the average for the control class of 53.50. It is stated that the learning outcomes of the experimental class are higher than the control class.
\end{abstract}

\section{A B STRAK}

Tujuan penelitian ini untuk mengetahui rata-rata hasil belajar peserta didik
dengan media video animasi. Penelitian ini merupakan penelitian
eksperimen pada kelas XI MIA dengan satu kelas eksperimen dan satu kelas
kontrol masing-masing kelas terdiri dari 30 peserta didik. Data hasil
penelitian ini yaitu rata-rata untuk kelas eksperimen 86,40 dan rata-rata
untuk kelas kontrol 53,50. Hal ini bahwa rata-rata hasil belajar kelas
eksperimen lebih tinggi dari kelas kontrol.

\section{Pendahuluan}

Peserta didik dengan lingkungan harus berinteraksi agar dapat mencapai tujuan pembelajaran [1]. Sekitar $80 \%$ peserta didik di SMAN 1 Bolaang tidak minat belajar meteri kimia, karena materi kimia merupakan materi yang sangat sulit untuk dipelajari.

Kegiatan pembelajaran di SMAN 1 Bolaang hanya dilakukan melalui metode ceramah sehingga peserta didik hanya menulis atau mencatat apa yang didengar dan dijelaskan oleh guru tanpa dilibatkan langsung dalam proses menemukan atau mengembangkan pengetahuan peserta didik. Subjek dalam proses kegiatan belajar mengajar adalah peserta didik dengan masing-masing peserta didik berkemampuan dan karakter berbeda sehingga ada yang mudah memahami dan yang rumit memahami materi kimia [2].

Hasil wawancara dengan para guru dan peserta didik di kelas XI MIA di SMAN 1 Bolaang, materi kimia merupakan pembelajaran yang mana dalam proses belajar harus melakukan kegiatan praktikum.
Praktikum tidak dilakukan karena alat dan bahan yang tidak lengkap, guru menganggap bahwa praktikum kimia sangat membutuhkan waktu yang panjang untuk mempersiapkan atau melaksanakan praktikum. Hal ini membuat peserta didik sulit untuk memahami materi yang diberikan, ditinjau dari permasalahan tersebut, didapatkan nilai semester ganjil tahun 2018/2019 di kelas XI MIA SMAN 1 Bolaang dari 105 peserta didik hanya $28 \%$ di atas nilai KKM dan $72 \%$ di bawah nilai KKM, sedangkan peserta didik harus mencapai nilai KKM dengan 77 sehingga nila belajar dari peserta didik bisa dikatakan rendah.

Media pembelajaran dapat bermanfaat sebagai media atau alat yang memudahkan peserta didik dalam proses memahami materi sehingga hasil belajar peserta didik dapat meningkat serta memperluas materi berdasarkan ilustrasi dalam media dari tujuan pembelajaran kimia [3].

Media pembelajaran yang akan digunakan dalam penelitian ini adalah media berbasis video animasi. Media berbasis video animasi 
merupakan media yang belum pernah diterapkan pada pembelajaran kimia kelas XI MIA di SMAN 1 Bolaang. Media pembelajaran berbasis video animasi digunakan agar dapat membantu peserta didik dalam memahami materi pada proses kegiatan belajar mengajar [4]. Mempermudah guru untuk memberikan pengajaran kepada peserta didik karena adanya media berbasis video animasi guru bisa memberikan materi secara berulang-ulang tanpa melakukan praktikum basah [5]. Melalui video animasi dapat menunjukkan prosedur jalannya praktikum dengan baik, mudah diingat dan dimengerti, video animasi berisi konten-konten berupa ilustrasi yang menarik perhatian, peserta didik tidak merasa jenuh dan bosan saat menerima materi [6-8]. Untuk menghasilkan video animasi yang lebih baik pengembangan dengan menggunakan aplikasi telah banyak dilakukan [9-13]. Video animasi telah terbukti meningkatkan hasil belajar dibandingkan dengan metode konvensional [14-16].

\section{Metode}

Penelitian ini dilakukan di SMAN 1 Bolaang. Jenis penelitian ini adalah penelitian eksperimen dengan posttest only control group design.

\section{Hasil dan Pembahasan}

\section{Hasil Uji Instrumen Penelitian}

Uji Validitas

Uji Validitas pada penelitian ini yaitu menggunakan korelasi Pearson Product Moment dari 20 butir soal pilihan ganda terdapat 6 soal tidak valid dan 14 butir soal yang valid. Maka, soal yang digunakan sebagai alat ukur hasil belajar adalah 14 butir soal pilihan ganda

\section{Uji Reliabilitas}

Uji reliabilitas dalam penelitian ini yaitu menggunakan teknik belah dua dari Spearman Brown (split half), dengan diperoleh perhitungan data $\mathrm{rHitung}=0,79$ dan $\mathrm{r}_{\text {Tabel }}=0,48$. Maka, posttest dinyatakan reliabel karena rHitung > rTabel, sehingga soal posttest tersebut layak dijadikan instrumen penelitian.
Hasil Uji Prasyarat

Uji Normalitas

Uji Normalitas digunakan untuk mengetahui sebaran data populasi dalam penelitian ini berdistribusi normal. Uji normalitas yang dipakai adalah uji Lillifors dengan Lhitung $=0,15$ dan Ltabel $=0,16$ dan kelas kontrol diperoleh Lhitung $=0,15$ dan Ltabel $=$ 0,16 dengan kriteria pengujian Lhitung < Ltabel, maka sampel yang diteliti berdistribusi normal.

\section{Uji Homogenitas}

Hasil uji homogenitas pada kelas eksperimen dan kelas kontrol diperoleh $F_{\text {hitung }}=$ 2,71 dan $F_{\text {tabel }}=3,16$ dengan kriteria pengujian yaitu $F_{\text {hitung }}<\mathrm{F}_{\text {tabel, }}$ maka varians kedua kelas tersebut dinyatakan bahwa kelas yang dijadikan subjek penelitian memiliki kemampuan yang homogen untuk menerima materi yang diberikan.

\section{Hasil Uji Hipotesis Penelitian}

Uji hipotesis dalam penelitian ini yaitu menentukan hasil posttest untuk mengetahui rata-rata hasil belajar peserta didik dengan penerapan media pembelajaran berbasis video animasi.

Tabel 1. Uji Hipotesis

\begin{tabular}{ccc}
\hline \multirow{2}{*}{ Statistik } & \multicolumn{2}{c}{ Nilai Statistik Posttest } \\
\cline { 2 - 3 } & $\begin{array}{c}\text { Kelas } \\
\text { Eksperimen }\end{array}$ & Kelas Kontrol \\
\hline (N) & 30 & 30 \\
Rata-rata & 86,40 & 53,50 \\
Varians & 55,90 & 151,78 \\
thitung & \multicolumn{2}{c}{12,51} \\
ttabel & \multicolumn{3}{c}{2,000} \\
Kesimpulan & \multicolumn{2}{c}{ Terima $\mathrm{H}_{1}$} \\
\end{tabular}

Hipotesis penelitian ini adalah $\mathrm{H}_{0}$ : Ratarata hasil belajar peserta didik dengan menggunaakan media video animasi lebih rendah atau sama dengan rata-rata hasil belajar menggunakan metode ceramah. $\mathrm{H}_{1}$ : Rata-rata hasil hasil belajar peserta didik dengan menggunakan media video animasi lebih tinggi dari pada rata-rata hasil belajar peserta didik dengan menggunakan metode ceramah. Hasil uji hipotesis yang dapat dilihat pada tabel 1 . 
Berdasarkan tabel 1 dapat dilihat bahwa hasil pengujian dengan uji-t pada taraf nyata $(\alpha$ $=0,05)$ diperoleh thitung $=12,51$ dan tabel $=2,00$, kriteria pengujian yaitu thitung $>t_{\text {tabel, }}$ maka $\mathrm{H}_{a}$ diterima dan $\mathrm{H}_{0}$, dengan diperoleh $\mu_{1}=86,40>$ $\mu_{2}=53,50$, sehingga dapat dinyatakan bahwa rata-rata hasil belajar peserta didik dengan menggunakan media video animasi lebih tinggi dari rata-rata hasil belajar peserta didik dengan menggunakan metode ceramah.

\section{Pembahasan Penelitian}

Penelitian ini dilaksanakan di SMAN 1 Bolaang, dengan menggunakan dua kelas yaitu untuk kelas eksperimen adalah kelas XI MIA 2 dan untuk kelas kontrol adalah kelas XI MIA3. Untuk mengetahui rata-rata hasil belajar peserta didik diperlukan pengambilan data. Penelitian ini dilakukan selama lima kali pertemuan, yaitu pada pertemuan pertama sampai pertemuan keempat untuk kelas XI MIA 2 sebagai kelas eksperimen dengan menggunakan media video animasi dan XI MIA 3 sebagai kelas kontrol dengan menggunakan metode ceramah yaitu diberikan materi tentang pengertian dan pengukuran laju reaksi, hukum laju reaksi, teori tumbukan dan faktor-faktor yang mempengaruhi laju reaksi.

Pada kelas eksperimen disajikan materi video animasi dalam slide powerpoint, pada saat menyajikan materi seperti teori tumbukan yang memperlihatkan bagaimana tumbukan yang efektif yang disertai dengan contoh tumbukan plastisin dan video animasi yang berisi percobaan mengenai faktor-faktor yang mempengaruhi laju reaksi seperti faktor konsentrasi, luas permukaan, suhu dan katalis, dalam penyajian materi peserta didik terlihat penasaran dengan animasi-animasi menarik yang ditayangkan dalam video, dan peserta didik juga penasaran dengan tampilan video animasi pada slide selanjutnya, peserta didik fokus dan tenang dengan video yang ditayangkan sehingga jika ada peserta didik yang ribut atau menggangu peserta didik yang lain maka peserta didik langsung menegur untuk tidak membuat keributan agar tidak terganggu dengan proses pembelajaran, dan apabila peserta didik masih belum paham dengan materi yang diberikan, maka video tersebut bisa ditayangkan kembali sampai peseta didik tersebut paham, pada saat memberikan pertanyaan kepada peserta didik, peserta didik begitu cepat tanggap sehingga adanya interaksi baik antara guru dengan peserta didik dan peserta didik dengan peserta didik lainnya.

Pada kelas kontrol diberikan materi yang sama seperti pada kelas eksperimen dengan metode ceramah. Pada saat memberikan materi, diamati bahwa pada kelas kontol peserta didik hanya berpusat pada guru dan hanya mencatat apa yang dijelaskan oleh guru, banyak peserta didik yang keluar masuk kelas seperti merasa bosan dan ada peserta didik yang mengantuk pada saat pembelajaran berlangsung.Setelah proses kegiatan belajar dilakukan, pada pertemuan kelima yaitu dilanjutkan dengan tahap pengambilan data dengan memberikan posttest dalam bentuk pilihan ganda yang valid pada kelas eksperimen adalah kelas XI MIA 2 dan kelas kontrol adalah kelas XI MIA 3 dengan masing-masing kelas yang mengikuti posttest terdiri dari 30 peserta didik. Pada saat memberikan posttest kepada peserta didik, maka diawasi dengan teliti bahwa peserta didik menjawab posttest dengan jujur dan sesuai dengan apa yang peserta didik peroleh dari kegiatan belajar mengajar. Berdasarkan pengambilan data dari hasil penelitian yang telah dilakukan, yaitu dengan menerapkan media video animasi diperoleh nilai minimum 71 dari hasil posttest pada kelas eksperimen dan untuk kelas kontrol diperoleh nilai maksimum 100 dengan nilai rata-rata 86,40 dengan metode ceramah diperoleh nilai minimum 21 dan nilai maksimum 79 dengan nilai rata-rata 53,50. Hasil tersebut ternyata menunjukkan bahwa rata-rata hasil belajar dengan menerapkan media video animasi lebih tinggi daripada ratarata hasil belajar dengan metode ceramah $\left(\mathrm{H}_{1}: \mu_{1}>\mu_{2}\right)$. Maka, hipotesis yang digunakan pada penelitian ini yaitu terima $\mathrm{H}_{1}$ dan tolak $\mathrm{H}_{0}$, karena dengan adanya media video animasi pembelajaran akan lebih efektif, peserta didik mulai berani untuk mengungkapkan pendapat, baik untuk bertanya maupun menanggapi pertanyaan. Menurut Yunita dan Wijayanti (2017) media video animasi dapat membuat peserta didik lebih aktif dalam proses kegiatan pembelajaran, yaitu peserta didik mampu berpartisipasi dan antusias serta meningkatkan 
pengetahuan, daya imajinasi dan daya berpikir kritis. seperti penelitian Nurhayati (2014) menuliskan pembelajaran berbasis media video animasi dapat mempermudah peserta didik untuk memahami materi yang diberikan dan dapat dijadikan sebagai alat dalam proses pembelajaran, serta dapat memberikan pengalaman yang baik bagi peserta didik, dengan hasil penelitian menunjukkan bahwa nilai kelas eksperimen 72,19 dan kelas kontrol 63,67 , sehingga didapatkan dari hasil belajar dengan media berbasis video animasi lebih tinggi dari pada rata-rata hasil belajar peserta didik dengan metode ceramah.

\section{Kesimpulan}

Dapat disimpulkan bahwa nilai rata-rata hasil belajar peserta didik menggunakan media video animasi lebih tinggi dari pada nilai ratarata hasil belajar peserta didik dengan metode ceramah.

\section{Daftar Pustaka}

1. Arifin, R.W.; Septanto, H.; Wignyowiyoto, I. Pengembangan Media Pembelajaran Berbasis Video Animasi Dengan Model ADDIE Dalam Kegiatan Pembelajaran Blended Learning. Inf. Manag. Educ. Prof. 2018, 2, 179-188.

2. Jannah, M.; Copriady, J.; Rasmiwetti, R. Development of Interactive Learning Media using Autoplay Media Studio 8 for Colloidal Chemistry Material. J. Educ. Sci. 2019, 3, 132-144, doi:10.31258/jes.3.1.p.132144.

3. Lou, S.-J.L.H.-C.S.R.-C.T.K.-H. Improving the Effectiveness of Organic Chemistry Experiments through Multimedia Teaching Materials for Junior High School Students. Turkish Online J. Educ. Technol. 2012, 11, 135-141.

4. Ole, A.A.; Simandjuntak, S.; Tumbel, F.M. Pengembangan Media Pembelajaran Sains Melalui Video Animasi Berbasis PBL. CogITo Smart J. 2019, 5, 12-21, doi:10.31154/cogito.v5i1.146.12-21.

5. Velázquez-Marcano, A.; Williamson, V.M.; Ashkenazi, G.; Tasker, R.; Williamson, K.C. The Use of Video Demonstrations and Particulate Animation in General Chemistry. J. Sci. Educ. Technol. 2004, 13,
315-323, doi:10.1023/b:jost.0000045458.76285.fe.

6. Turkoguz, S. Learn to teach chemistry using visual media tools. Chem. Educ. Res. Pract. 2012, 13, 401-409, doi:10.1039/c2rp20046e.

7. Rodrigues, S.; Smith, A.; Ainley, M. Video clips and animation in chemistry CDROMS: Student interest and Preference ProQuest. Aust. Sci. Teach. J. 2001, 47, 9-16.

8. Pekdag, B. Alternative Methods in Learning Chemistry: Learning with Animation, Simulation, Video and Multimedia. J. Turkish Sci. Educ. 2010, 7, 79110.

9. Pangestu, R.D.; Mayub, A.; Rohadi, N. Pengembangan Desain Media Pembelajaran Fisika SMA Berbasis Video pada Materi Gelombang Bunyi. J. Kumparan Fis. 2018, 1, 48-55.

10. Fitriani, O.; Susilawati, S.; Linda, R. Development of Interactive Learning Media using Autoplay Studio 8 for Hydrocarbon Material of Class XI Senior High School. J. Educ. Sci. 2020, 4, 296-308.

11. Qonita Silmi, M.; Rachmadyanti, P. Pengembangan media pembelajaran video animasi berbasis sparkol videoscribe tentang persiapan kemerdekaan RI SD kelas V. J. Penelit. Pendidik. Guru Sekol. Dasar 2018, 6, 486-495.

12. Agustien, R.; Umamah, N.; Sumarno, S. Pengembangan media pembelajaran video animasi dua dimensi situs Pekauman di Bondowoso dengan model ADDIE mata pelajaran Sejarah kelas X IPS. J. Edukasi 2018, 5, 19-23.

13. Wuryanti, U.; Kartowagiran, B. Pengembangan media video animasi untuk meningkatkan motivasi belajar dan karakter kerja keras siswa sekolah dasar. J. Pendidik. Karakter 2016, 6, 232-245.

14. Johari, A.; Hasan, S.; Rakhman, M. Penerapan Media Video dan Animasi pada Materi Memvakum dan Mengisi Refrigeran terhadap Hasil Belajar Siswa. J. Mech. Eng. Educ. 2014, 1, 8-15, doi:10.17509/jmee.v1i1.3731.

15. Masitoh, U.; Hayadi, H.; Purnawan, P. Penerapan Media Pembelajaran Animasi Sebagai Upaya untuk Meningkatkan Hasil 
Belajar Mata Kuliah Otomasi. J. Mech. Eng. Educ. 2015, 2, 145-151, doi:10.17509/jmee.v2i1.1165.

16. Arfika, F.; Chalid, S. Penerapan Media Berbasis Video Tutorial Untuk Meningkatkan Hasil Belajar Membuat Kampuh Siswa Kelas X Smk Negeri 1 Stabat. SILUET (Jurnal Pendidik. Tata Busana) 2017, 1, 30-38. 